\title{
Pemanfaatan Limbah Cair Aren untuk Pupuk dengan Berbagai Starter Dekomposisi terhadap Pertumbuhan dan Hasil Jagung
}

\section{Utilization of Sugar Palm Liquid Waste for Fertilizer with Variety of Decomposition Starters on The Growth and Yield of Maize}

\author{
Ahmad Nurcahyo ${ }^{1)}$, Supriyono ${ }^{2)}$, Purwanto ${ }^{2)}$
}

\begin{abstract}
Sugar palm (Arenga pinnata) flour industry in Tulung, Klaten district is the center of the sugar palm flour production industry in Central Java. In the processing of sugar palm flour is a lot of obstacles, one of which is environmental pollution resulting from waste liquid produced. This reasearch was purposed to determine the effect of liquid organic sugar palm fertilizer with a variety of decomposition starters on the growth and yield of maize. The research was held from September to December 2014 at the Greenhouse of Faculty of Agriculture, Sebelas Maret University (UNS) of Surakarta with the design used was Randomized Complete Block Design (RCBD) that there is one factor, that is a variety of decomposition starters. The treatment of each repeated four times in order to obtain 24 plots. The results showed that fertilization using sugar palm liquid waste fermented with variety of decomposition starters have no significant effect on the growth and yield of maize. The combination treatment of sugar palm liquid waste fertilizer fermented with EM-4 resulted higher yield potency grain per cob is 36,49 grain or $7,3 \%$ of normal production grain per cob.
\end{abstract}

Keywords : sugar palm waste, decomposer, liquid organic fertilizer, maize

\section{PENDAHULUAN}

Industri tepung aren di Kecamatan Tulung, Kabupaten Klaten merupakan sentra industri produksi tepung aren di wilayah Jawa Tengah. Dalam proses pengolahan aren tersebut banyak terdapat kendala, salah satunya yaitu pencemaran lingkungan akibat dari limbah cair yang dihasilkan. Limbah cair berasal dari proses penyaringan dan pengendapan tepung aren. Menurut Firdayati dan Handajani (2005), limbah cair yang dihasilkan oleh pabrik tepung aren di Dukuh Bendo, Kecamatan Tulung mengandung BOD (Biological Oxygen Demand) dan COD (Chemycal Oxygen Demand) yang cukup tinggi yaitu masingmasing 2222 mg liter ${ }^{-1}$ dan $5722 \mathrm{mg} \mathrm{liter}^{-1}$ dan menjadi pencemar bagi lingkungan sekitarnya. Kebanyakan dari industri tepung aren di daerah tersebut mengalirkan limbah cair aren langsung ke lingkungan tanpa diolah terlebih dahulu sehingga menyebabkan pencemaran air dan tanah yang ada di sekitar industri tepung aren, selain itu juga akan berdampak pada tanaman, hewan dan manusia yang ada disekitarnya.

Alternatif pengolahan limbah aren yang pernah dilakukan yaitu berupa penggunaan limbah aren padat yang sebagai media tanam dalam budidaya jamur, warga sekitar juga memanfaatkan limbah cair untuk menyirami tanaman padi, tetapi berdampak kurang baik terhadap petumbuhan tanaman, sehingga

\footnotetext{
1) Undergraduate Student of Study Program of Agrotechnology, Faculty of Agriculture, University of Sebelas Maret (UNS) on Surakarta

2) Lecturer Staff of Study Program of Agrotechnology, Faculty of Agriculture, University of Sebelas Maret (UNS) on Surakarta

Contact Author: ahmadnurcahyo9@gmail.com
}

muncul gagasan untuk memanfaatkan limbah cair aren tersebut dengan pengolahan lebih lanjut sebagai pupuk organik cair dengan penambahan beberapa starter dekomposisi untuk dapat merombak bahan organik limbah aren menjadi unsur yang tersedia untuk pertumbuhan pada tanaman jagung. Jagung merupakan salah satu tanaman pangan yang banyak dibudidayakan di Indonesia, sehingga diharapkan dapat menjadi substitusi pupuk anorganik yang selama ini banyak digunakan oleh petani untuk budidaya jagung.

Tujuan dari penelitian ini adalah untuk mengetahui pengaruh pemberian pupuk organik cair aren dengan berbagai starter dekomposisi terhadap pertumbuh-an jagung, mengetahui starter dekompo-sisi yang efektif untuk pembuatan pupuk organik cair aren dan untuk memperoleh formulasi pupuk organik cair aren dan starter dekomposisi yang optimal untuk meningkatkan pertumbuhan dan hasil jagung.

\section{METODE PENELITIAN}

Pembuatan pupuk dilaksanakan pada bulan JuliAgustus 2014, penanaman jagung dilaksanakan pada bulan September-Desember 2014 di Rumah Kaca Fakultas Pertanian Universitas Sebelas Maret Surakarta. Analisis pupuk dilaksanakan pada bulan Agustus 2014 di Laboratorium Biologi Tanah dan di Laboratorium Kimia dan Kesuburan Tanah. Bahan yang digunakan pada percobaan ini adalah benih jagung komposit varietas Bisma, limbah cair aren, EM -4 , starter isi usus ayam, starter rumen sapi, starter sisa organik sayuran sawi dan gula merah. Alat yang digunakan adalah polibag (diameter $45 \mathrm{~cm}$ ), jrigen, ember, peralatan budidaya tanaman dan peralatan ukur. Percobaan ini menggunakan Rancangan Acak Kelompok Lengkap (RAKL) yang terdapat satu faktor, 
yaitu faktor variasi starter dekomposisi. Terdapat enam perlakuan meliputi $\mathrm{P} 0=$ Kontrol, $\mathrm{P} 1=$ Limbah cair aren, P2= Limbah cair aren difermentasi dengan EM-4 (sebagai pembanding perlakuan limbah cair aren dan starter), P3= Limbah cair aren difermentasi dengan starter rumen sapi, P4= Limbah cair aren difermentasi dengan starter isi perut ayam, P5= Limbah cair aren difermentasi dengan starter sisa organik sayuran sawi. Dari perlakuan tersebut masing-masing diulang empat kali sehingga diperoleh 24 plot.

Variabel pengamatan penelitian meliputi tinggi tanaman, jumlah daun, indeks luas daun, berat tongkol segar per tanaman, jumlah biji per tongkol, berat 1000 biji, berat segar berangkasan dan berat kering berangkasan tanaman. Data hasil pengamatan dianalisis menggunakan analisis ragam (Annova) dengan uji taraf $5 \%$ dan apabila terdapat beda nyata dilanjutkan dengan Uji DMRT taraf $5 \%$.

\section{HASIL DAN PEMBAHASAN}

\section{Kondisi Tempat Penelitian}

Penelitian dilaksanakan di Rumah Kaca A Fakultas Pertanian Universitas Sebelas Maret Surakarta, Jawa Tengah. Posisi geografis tempat tersebut terletak pada $7^{0} 33^{\prime} 41^{\prime \prime}$ LS dan $110^{\circ} 51^{\prime} 32^{\prime \prime}$ BT, sedangkan tinggi tempat yaitu $110 \mathrm{~m}$ diatas permukaan laut dengan menggunakan media tanah Alfisols. Lokasi penelitian selain digunakan untuk penelitian jagung digunakan untuk penelitian tanaman lain seperti padi, tomat, kedelai dan kacang tanah sehingga terdapat keragaman jenis tanaman dari tempat penelitian tersebut. Penelitian ini dilaksanakan pada bulan September 2014 sampai Desember 2014. Berdasarkan data suhu rumah kaca FP UNS selama penelitian berlangsung berkisar antara $34-39^{\circ} \mathrm{C}$. Hasil analisis tanah sebelum perlakuan disajikan pada tabel 1.

Tabel 1. Karakteristik tanah awal alfisols

\begin{tabular}{llll}
\hline Sifat Kimia Tanah & Satuan & Hasil & Pengharkatan*) $^{\star}$ \\
\hline $\mathrm{N}-$ Total & $\%$ & 119 & Sangat rendah \\
$\mathrm{P}_{2} \mathrm{O}_{5}$ & $\mathrm{ppm}$ & 120 & Sangat rendah \\
$\mathrm{K}_{2} \mathrm{O}$ & $\mathrm{me} \%$ & 500 & Sedang \\
$\mathrm{Kadar}$ Bahan Organik & $\%$ & 738 & Sangat rendah \\
$\mathrm{pH}$ & - & 980 & Agak masam \\
$\mathrm{C}-$ Organik & $\%$ & 428 & Sangat rendah \\
\hline
\end{tabular}

*) = Pengharkatan menurut Balai Penelitian Tanah (2005)

Sumber: Hasil Analisis di Laboraturium Kimia Tanah FP UNS Surakarta 2014.

\section{Hasil Analisis Pupuk}

Hasil analisis pupuk cair aren menunjukkan bahwa pupuk limbah cair aren difermentasi dengan EM-4 merupakan kombinasi perlakuan yang memiliki kandungan unsur hara paling tinggi dibandingkan dengan perlakuan yang lain yaitu dengan kandungan $\mathrm{N}$-total 0,049\%, P-total 456,756 ppm, K-total 1063 ppm, C-Organik 0,956 \% dan BO 1,649\% dan pH 7,3 (netral), sedangkan untuk perlakuan yang lain kandungan unsur $\mathrm{N}, \mathrm{P}, \mathrm{K}$-total, C-organik dan $\mathrm{BO}$ yang hampir sama untuk semua perlakuan dengan $\mathrm{pH}$ berkisar antara 4,1-5,4 (masam). Menurut Cesaria et al. (2013), peningkatan kandungan $\mathrm{pH}$ dan kemudian mengalami penurunan pada akhir proses fermentasi disebabkan oleh tingginya aktivitas kelompok bakteri seperti bakteri metanogen yang mengkonversikan asam-asam organik menjadi senyawa yang lebih sederhana seperti metana, amoniak dan karbondioksida sehingga mengalami proses perubahan dari $\mathrm{pH}$ asam menuju pada kondisi yang optimal yaitu $\mathrm{pH}$ mendekati netral $(\mathrm{pH} 7)$, terutama pada perlakuan pupuk limbah cair aren difermentasi dengan EM-4. Kemasaman pupuk akan mempengaruhi reaksi kemasaman dalam tanah menjadi meningkat. Hal tersebut akan berpengaruh terhadap ketersediaan hara di dalam tanah. Jumlah terbesar unsur hara esensial tersedia pada kisaran kondisi $\mathrm{pH}$ antara 5,2 - 6,5. Di atas dan di bawah kisaran tersebut, sebagian unsur hara akan terikat kuat oleh partikel tanah dan tidak tersedia bagi tanaman.

Tabel 2. Kandungan unsur hara pupuk cair aren

\begin{tabular}{lllllll}
\hline \multirow{2}{*}{ Parameter } & \multirow{2}{*}{ Satuan } & \multicolumn{5}{c}{ Hasil } \\
\cline { 3 - 7 } & & $\mathrm{P} 1$ & $\mathrm{P} 2$ & $\mathrm{P} 3$ & $\mathrm{P} 4$ & $\mathrm{P} 5$ \\
\hline N-Total & $\%$ & 0,052 & 0,049 & 0,056 & 0,066 & 0,052 \\
P-Total & $\mathrm{ppm}$ & 454,368 & 456,756 & 463,92 & 514,068 & 509,292 \\
K-Total & $\mathrm{ppm}$ & 746,800 & 1063,000 & 914,800 & 576,400 & 1006,000 \\
C-Organik & $\%$ & 0,471 & 0,956 & 0,545 & 0,626 & 0,566 \\
$\mathrm{pH}$ & - & 4,510 & 7,370 & 4,140 & 5,100 & 5,400 \\
C/N ratio & - & 9,010 & 19,530 & 9,750 & 9,470 & 10,810 \\
Kadar BO & $\%$ & 0,8133 & 1,649 & 0,941 & 1,081 & 0,976 \\
\hline
\end{tabular}




\section{Tinggi Tanaman}

Hasil analisis ragam menunjukkan bahwa pemupukan limbah cair aren difermentasi dengan berbagai starter dekomposisi tidak memberikan pengaruh nyata terhadap tinggi tanaman. Berdasarkan Gambar 1 dapat diketahui bahwa pertambahan tinggi tanaman tiap perlakuan hampir sama di setiap minggu, dengan rata-rata tinggi tanaman paling tinggi yaitu pada pemupukan menggunakan limbah cair aren difermentasi dengan EM -4 dengan tinggi tanaman sebesar 194,75 cm, dengan rata-rata paling rendah yaitu pada pemupukan menggunakan limbah cair aren difermentasi dengan sisa organik sayuran sebesar $162,75 \mathrm{~cm}$. Hal ini diduga terjadi karena penyerapan unsur hara pupuk oleh tanaman yang tidak optimal. Menurut Parman (2007), pemberian pupuk cair dengan cara pengocoran langsung kurang efektif karena berbagai unsur hara yang ada telah larut lebih dahulu dan mengalami fiksasi oleh koloid tanah sehingga tidak dapat diserap oleh tanaman seluruhnya.

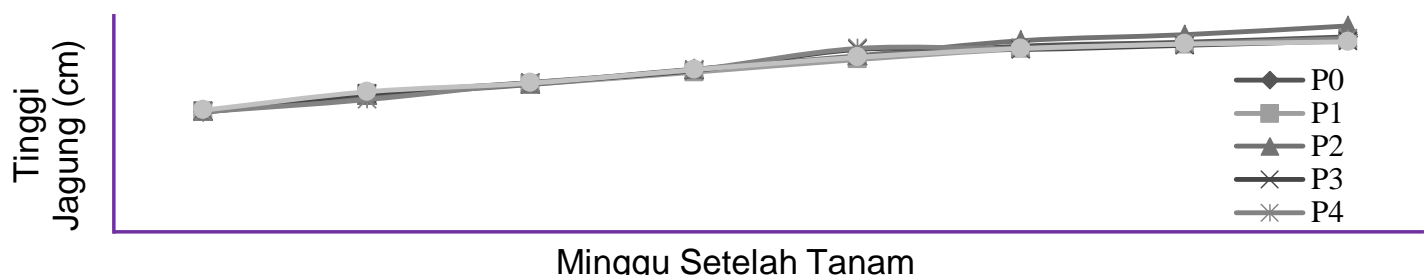

$\mathrm{P} 0=$ Kontrol, $\mathrm{P} 1=$ Limbah cair aren, $\mathrm{P} 2=$ Limbah cair aren difermentasi dengan $\mathrm{EM}-4, \mathrm{P} 3=$ Limbah cair aren difermentasi dengan starter rumen sapi, $\mathrm{P} 4=$ Limbah cair aren difermentasi dengan starter isi usus ayam, P5= Limbah cair aren difermentasi dengan starter sisa organik sayuran sawi.

Gambar 1. Pola pertumbuhan jagung (Zea mays)

\section{Variabel Pertumbuhan dan Hasil Jagung}

Pertumbuhan membutuhkan ukuran secara tepat dan dapat dibaca dengan bentuk kuantitatif yang dapat diukur. Pertumbuhan tanaman merupakan peristiwa perubahan biologis yang terjadi pada tanaman berupa perubahan ukuran, bentuk dan volume yang bersifat irreversible dan berjalan secara simultan.

\section{Jumlah Daun dan Indeks Luas Daun}

Pemupukan limbah cair aren difermentasi dengan berbagai starter dekomposisi tidak memberikan pengaruh nyata terhadap rata-rata jumlah daun dan indeks luas daun. Berdasarkan Tabel 3 dapat diketahui bahwa rata-rata jumlah daun tertinggi terdapat pada pemupukan limbah cair aren difermentasi dengan rumen sapi yaitu 10,75 helai tidak berbeda nyata dengan perlakuan yang lain yaitu dengan rata-rata jumlah daun berkisar antara 9-10 daun. Hal ini diduga karena unsur yang tersedia dalam pupuk organik cair tidak dapat mencukupi untuk pertumbuhan dan pembentukan daun tanaman, sehingga kebutuhan unsur hara untuk pertumbuhan vegetatif terutama daun tidak dapat terpenuhi terutama unsur hara $\mathrm{N}$ yang berperan penting untuk pertumbuhan vegetatif tanaman. Sedangkan untuk rata-rata indeks luas daun paling tinggi yaitu pada pemupukan mengguna-kan limbah cair aren difermentasi dengan EM-4 sebesar 1,33 tidak berbeda nyata dengan perlakuan yang lain yaitu berkisar antara 0,93-1,08. Hal ini diduga disebabkan karena unsur hara yang terkandung dalam pupuk cair aren mempunyai kandungan unsur hara yang relatif sama terutama unsur $\mathrm{N}$ sehingga memberikan pengaruh yang cenderung sama terhadap indeks luas daun. Menurut Gardner et al. (1991), unsur hara N dalam hal ini merupakan bagian utuh dari struktur klorofil dan warna hijau daun. Stewart et al. (2003) menambahkan bahwa faktor lain yang mempengaruhi indeks luas daun yaitu jumlah daun, sebaran dan sudut daun pada suatu tajuk tanaman.

Tabel 3. Rerata pertumbuhan dan hasil jagung yang dipupuk dengan limbah cair aren dan starter dekomposisi

\begin{tabular}{lrrrrrr}
\hline \multirow{2}{*}{ Varabel Pengamatan } & \multicolumn{7}{c}{ Perlakuan } \\
\cline { 2 - 6 } & $\mathrm{P} 0$ & $\mathrm{P} 1$ & $\mathrm{P} 2$ & $\mathrm{P} 3$ & $\mathrm{P} 4$ & $\mathrm{P} 5$ \\
\hline Jumlah Daun (helai) & 9,00 & 10,00 & 9,00 & 10,75 & 9,50 & 9,25 \\
\hline Indeks Luas Daun & 0,93 & 1,06 & 1,33 & 1,08 & 1,04 & 1,01 \\
\hline Berat Tongkol Segar per Tanaman (gram) & 10,78 & 14,85 & 31,75 & 20,84 & 21,29 & 24,40 \\
\hline Jumlah Biji per Tongkol (biji) & 8,95 & 12,80 & 36,49 & 18,86 & 7,43 & 16,52 \\
\hline Berat 1000 Biji (gram) & 246,64 & 236,76 & 228,82 & 323,56 & 239,64 & 283,69 \\
\hline Berat Segar Berangkasan(gram) & 98,82 & 88,59 & 125,53 & 87,37 & 87,82 & 78,62 \\
\hline Berat Kering Berangkasan (gram) & 29,78 & 23,74 & 41,75 & 22,48 & 26,36 & 21.98 \\
\hline
\end{tabular}

$\mathrm{P} 0=$ Kontrol, $\mathrm{P} 1=$ Limbah cair aren, $\mathrm{P} 2=$ Limbah cair aren difermentasi dengan EM-4, P3= Limbah cair aren difermentasi dengan starter rumen sapi, P4= Limbah cair aren difermentasi dengan starter isi usus ayam, P5= Limbah cair aren difermentasi dengan starter sisa organik sayuran sawi.

Berat Tongkol Segar per Tanaman

Pemanfaatan Limbah Cair Aren untuk Pupuk dengan Berbagai

Ahmad Nurcahyo, Supriyono, Purwanto
Pemupukan limbah cair aren difermentasi dengan berbagai starter dekomposisi tidak berpengaruh nyata terhadap berat tongkol segar per tanaman. Rata-rata 
berat tongkol segar paling tinggi yaitu pada pemupukan jagung menggunakan limbah cair aren difermentasi dengan EM-4 sebesar 31,75 g tidak berbeda nyata dengan perlakuan yang lain yaitu berkisar antara 10,78-24,40 g dengan rata-rata berat tongkol segar paling rendah yaitu pada perlakuan kontrol (tanpa pemupukan aren) yaitu sebanyak 10,78 g. Hal ini diduga disebabkan oleh faktor unsur hara yang mempengruhi pembentukan tongkol jagung seperti unsur $\mathrm{P}$ dan $\mathrm{K}$ yang relatif kecil terutama pada pemupukan menggunakan limbah cair aren sehingga menghasikan berat tongkol yang rendah.

\section{Jumlah Biji per Tongkol}

Pemupukan limbah cair aren difermentasi dengan berbagai starter dekomposisi tidak memberikan pengaruh nyata terhadap jumlah biji per tongkol. Berdasarkan Tabel 3 dapat diketahui bahwa jumlah biji per tongkol paling tinggi yaitu pada pemupukan limbah cair aren difermentasi dengan EM-4 sebanyak 36,49 biji dengan potensi hasil pipilan kering sebanyak 0,3 ton ha $^{-1}$, tidak berbeda nyata dengan jumlah biji per tongkol yang paling rendah yaitu pada pemupukan limbah cair aren difermentasi dengan isi usus ayam dengan dengan jumlah biji per tongkol sebanyak 7,43 biji dan potensi hasil 0,06 ton ha ${ }^{-1}$, hasil tersebut tidak sesuai dengan potensi hasil pada deskripsi varietas jagung Bisma yaitu sekitar 5,7 ton ha $^{-1}$ pipilan kering. Hal ini diduga terjadi karena suplai unsur hara dari pupuk cair aren yang diberikan kemungkinan kurang mencukupi untuk pembentukan biji, terutama unsur hara K. Menurut Wangiyana et al. (2010), tanaman berbiji membutuhkan pasokan $\mathrm{K}$ dan $\mathrm{N}$ yang relatif tinggi selama pengisian biji untuk produksi fotosintat yang relatif tinggi untuk biji. Hal ini diduga karena unsur yang tersedia dalam pupuk organik cair tidak dapat mencukupi untuk pertumbuhan dan pembentukan daun tanaman, sehingga kebutuhan unsur hara untuk pertumbuhan vegetatif terutama daun tidak dapat terpenuhi terutama unsur hara $\mathrm{N}$ yang berperan penting untuk pertumbuhan vegetatif tanaman.

\section{Berat 1000 Biji}

Pemupukan limbah cair aren difermentasi dengan berbagai starter dekomposisi tidak memberikan pengaruh nyata terhadap berat 1000 biji. Berat 1000 biji paling tinggi yaitu pada pemupukan menggunakan limbah cair aren difermentasi dengan starter rumen sapi yaitu dengan berat 1000 biji sebesar 323,56 g dan paling rendah terdapat pada pemupukan limbah cair aren difermentasi dengan EM-4 yaitu 323,56 g. Hal ini diduga disebabkan karena tidak terpenuhi-nya unsur $\mathrm{P}$ dan $\mathrm{K}$ dari aplikasi pupuk yang dilakukan selama proses pengisian dan pembentukan biji sehingga pengisian biji tidak maksimal Menurut Marsono dan Sigit (2001), bahwa unsur $P$ berperan penting dalam mempercepat pembungaan dan pemasakan biji. Sedangkan unsur K sangat berperan dalam meningkatkan kuantitas dan kualitas hasil biji.

\section{Berat Segar Berangkasan}

Pemupukan limbah cair aren difermentasi dengan berbagai starter dekomposisi tidak memberikan pengaruh nyata terhadap berat segar berangkasan tanaman. Berat segar berangkasan tanaman jagung paling tinggi yaitu pada pemupukan menggunakan limbah cair aren difermentasi dengan starter EM-4 dengan berat segar berangkasan tanaman jagung sebesar 125,53 g tidak berbeda nyata dengan perlakuan yang lain. Berat segar berangkasan paling rendah sebanyak 78,62 g pada pemupukan limbah cair aren difermentasi dengan sisa organik sayuran sawi. Menurut Supriyono (2000), tingginya penyerapan air dan unsur hara oleh tanaman memungkinkan tanaman untuk tumbuh optimal dan akan berpengaruh terhadap meningkatnya berat berangkasan yang dihasilkan.

\section{Berat Kering Berangkasan}

Pemupukan limbah cair aren difermentasi dengan berbagai starter dekomposisi tidak memberikan pengaruh nyata terhadap berat kering berangkasan tanaman. Berat kering barangkasan paling tinggi yaitu pada pemupukan jagung menggunkan limbah cair aren difermentasi dengan EM -4 sebesar 41,75 gram, tidak berbeda nyata dengan perlakuan yang lain yaitu pada kisaran 21,98-29,78 g. Hal diduga disebabkan karena unsur hara yang diberikan dari pupuk organik cair pada tanah tidak dapat dimanfaatkan seluruhnya oleh tanaman untuk pembentukan bio-massa kering tanaman karena pengaruh $\mathrm{pH}$ tanah yang diduga masam akibat dari aplikasi pupuk limbah cair yang memiliki pH masam, sehingga berpengaruh ter-hadap ketersediaan hara yang rendah di dalam tanah. Menurut Parnata (2004), unsur hara merupakan salah satu faktor penting untuk menunjang pertumbuhan dan perkembangan tanaman karena unsur hara ini berperan sebagai sumber energi dan penyusun struktural tanaman.

\section{KESIMPULAN DAN SARAN}

\section{Kesimpulan}

Pemberian pupuk dari limbah cair aren difermentasi dengan berbagai starter dekomposisi meliputi EM-4, rumen sapi, isi usus ayam dan sisa organik sayuran tidak memberikan pengaruh pada pertumbuhan dan hasil jagung karena asupan unsur hara yang tidak memenuhi kebutuhan pemupukan pada tanaman jagung.

1. Pupuk dari limbah cair aren difermentasi dengan EM-4 merupakan komposisi yang memiliki kandungan unsur hara lebih tinggi dibandingkan perlakuan yang lain.

2. Kombinasi perlakuan pupuk dari limbah cair aren difermentasi dengan EM-4 cenderung memberikan potensi hasil terhadap pertumbuhan dan hasil jagung yaitu meliputi tinggi tanaman sebesar $194,75 \mathrm{~cm}$ atau $102,5 \%$ dari tinggi tanaman normal, hasil berat tongkol segar per tanaman sebesar $31,75 \mathrm{~g}$ atau $16,66 \%$ dari produksi berat tongkol segar normal, jumlah biji per tongkol sebanyak 36,49 biji atau 7,30\% dari produksi biji normal, berat segar berangkasan 125,53 g atau $29,93 \%$ dari berat segar berangkasan normal dan berat kering. 
3. berangkasan tanaman 41,75 gram atau $38,30 \%$ dari berat kering berangkasan normal.

\section{Saran}

Perlu adanya penyempurnaan mengenai metode yang digunakan dalam proses pembuatan pupuk, karena waktu yang dibutuhkan untuk proses pembuatan pupuk ini mulai dari fermentasi sampai matang relatif lama (1,5 bulan), sehingga dengan demikian diharapkan dapat menghasilkan pupuk dengan waktu pembuatan yang lebih singkat dengan nilai $\mathrm{C} / \mathrm{N}$ rasio yang rendah $(\mathrm{C} / \mathrm{N}$ rasio $10-20)$ dan memiliki kandungan unsur hara tinggi.

1. Aplikasi praktis di lapangan perlu diperhatikan yaitu berupa cara pengocoran pupuk pada tanah harus memperhatikan dosis pemupukan sehingga pupuk organik cair aren dapat menjadi suplai unsur hara untuk tanaman, selain itu apilikasi pupuk harus memperhatikan 5 Tepat yaitu tepat jenis, tepat dosis, tepat waktu, tepat tempat, dan tepat cara.

2. Pemberian pupuk harus sesuai atau mendekati dengan kebutuhan pemupukan jagung selama satu kali masa tanam yaitu $250 \mathrm{~kg} \mathrm{ha}^{-1}$ Urea, 100 $\mathrm{kg} \mathrm{ha}^{-1}$ SP-36 dan $75 \mathrm{~kg} \mathrm{ha}^{-1} \mathrm{KCl}$, sehingga kebutuhan hara tanaman dapat terpenuhi untuk pertumbuhan dan perkembangan tanaman.

3. Tempat penelitian sebaiknya dilahan terbuka, karena apabila ditanam di rumah kaca kemungkinan penyerbukan serta faktor pertumbuhan yang lain tidak dapat terpenuhi seluruhnya.

4. Penggunaan pot plastik atau pot tanah lebih disarankan dari pada polibag, karena pot tanah mempunyai konsistensi kuat sehingga evaporasi tanah dapat berjalan homogen dan aerasi tanah mendekati kondisi alamiah

\section{DAFTAR PUSTAKA}

Cesaria RY, Wirosoedarmo R, Suharto B. 2013. Pengaruh penggunaan starter terhadap kualitas fermentasi limbah cair tapioka sebagai alternatif pupuk cair. J Sumberdaya Alam dan Lingk 1(1): 814.

Firdayati M, Handajani M. 2005. Studi karakteristik dasar limbah industri tepung aren. J Infra dan Lingk Binaan 1(2): 22-29.

Gardner FP, Pearce RB, Mitcell RL 1991. Fisiologi tanaman budidaya. Susilo $H$ (Translator). Jakarta (ID): UI Press.

Marsono, Sigit P. 2001. Pupuk akar, jenis dan aplikasi. Jakarta (ID): Penebar Swadaya.

Parman S. 2007. Pengaruh pemberian pupuk organik cair terhadap pertumbuhan dan produksi kentang. Buletin Anatomi dan Fisiologi 15(2): 21-31.

Parnata AS 2004. Pupuk organik cair: Aplikasi dan manfaatnya. Jakarta (ID): Agromedia Pustaka.

Stewart DW, Costa C, Dwyer, Smith DL, Hamilton, Ma BL. 2003. Canopy structure, light interception, and photosynthesis in maize. J. Agron 95:1465-1474.

Supriyono. 2000. Pengaruh dosis urea tablet dan jarak tanam terhadap pertumbuhan dan hasil kedelai kultivar sindoro. J Agrosains 2(2): 1-10.

Syofia I, Munar A, Sofyan M. 2014. Pengaruh pupuk organik cair terhadap pertumbuhan dan hasil dua varietas tanaman jagung manis (Zea mays sacharata). J Agrium 18(3): 208-218.

Wangiyana W, Hanan M, Ngawit IK. 2010. Peningkatan hasil jagung hibrida var. Bisi-2 dengan aplikasi pupuk kandang sapi dan peningkatan frekuensi pemberian urea dan campuran SP-36 dan KCl. Fakultas Pertanian. Skripsi. Universitas Mataram. 